\title{
Challenges for the Land Consolidation Program and The Role of Community Participation in Residential Areas
}

\author{
Nany Yuliastuti ${ }^{1 *}$, Ragil Haryanto ${ }^{1}$, and Febriansyah Bima ${ }^{1}$ \\ ${ }^{1}$ Urban and Regional Planning Department, Diponegoro University, Indonesia
}

\begin{abstract}
In general, implementing land consolidation in big cities in Indonesia is still limited to developing public infrastructures such as road construction and drainage. There have not been many consolidation practices aimed at regulating land use arrangements to provide space for settlements. However, the concept of land consolidation has begun to be paid attention to strategies to increase the demand for housing amid the lack of land availability in urban areas. The purpose of the article is to assess the role of stakeholders in structuring residential land, using secondary data and is supported by interviews as primary data. Through the case study method in Tegalsari Village, Tegal City, the dimensions of the parts of each party were found. It was that all relevant stakeholders must consider more roles. Local governments, academics, practitioners, the private sector, and the community have equally essential functions, requiring mature collaboration to implement land consolidation successfully.
\end{abstract}

\section{Introduction}

Urbanization has changed the face of cities. The city turned into a city that has the primary function of services with various economic activities. This policy has accelerated urbanization in cities and has caused various development problems, including housing development. The increasing phenomenon of urbanization has led to high demand for housing [1]. During this development period, the role of land from time to time became more prominent and essential, both in its position as a factor of production and as a space to carry out various activities. Thus, the land is the principal capital and a dominant factor in the implementation of development.

Land problems are getting more and more complex from time to time, especially in urban areas. The high level of urbanization, causing an imbalance between the supply of land and the number of people who need land. As a result, residents make settlements irregularly or chaotic so that slums grow with low environmental quality due to the lack of infrastructure and environmental facilities needed [2]. Land consolidation can be an alternative to implement urban spatial planning effectively by distributing land ownership appropriately, and to meet urban development; the required infrastructure can be provided [3].

* Corresponding author: n.yuliastuti@pwk.undip.ac.id 
The implementation of land consolidation in Indonesia still faces many challenges. Some of the most critical challenges in implementing land consolidation are limited regional budgets, incompatibility between development in land consolidation activities and spatial planning, difficulty obtaining approval from landowners and landowner consensus, and difficulty agreeing on the percentage of the land donation. In the future, the challenge of land consolidation shifts to increasing land prices and decreasing the 'culture' of community participation. Then what is the solution? Some inputs for the land consolidation strategy in Indonesia are developing a roadmap and financing scheme that adapts the local community's character and strengthening institutional capacity and governance, creating a partnershipbased planning system based on community empowerment and self-reliance, and preparing technical guidelines.

The government took efforts in the land sector in land acquisition and improved environmental quality in urban areas by implementing urban land consolidation policies. Urban land consolidation is one of the development models related to the provision of land for road infrastructure and public facilities by involving the community and the private sector and a tangible manifestation of the implementation of social functions on land and creating a decent residential environment. The activities carried out by the city government with urban land consolidation must have a strong foundation because the implementation of these activities involves the public interest. With a strong foundation, urban land consolidation can be carried out correctly. Without any worries, after the urban land consolidation is implemented, it will cause new problems. As for the basis of urban land, consolidation is [4] whether land consolidation can be a form of community participation in integrated and participatory spatial planning. Therefore, the touch and active participation of the community significantly affect the success of spatial planning; primarily, they must provide an active role to maintain beauty, comfort, and sustainability so that it is not only the government that bears the burden [5]. Meanwhile, according to Yuliastuti and Haryanto [6], community factors and location factors affect land consolidation in alleviating slum areas through land consolidation.

The purpose of the study was to determine the possibility of land consolidation as an alternative form of community participation in spatial planning. Land consolidation has been practiced in various countries globally, such as Malaysia, Thailand, the Philippines, Australia, Japan, Taiwan, Netherlands, etc. $[6,7]$. Health Company USA13 said Germany was the first line of countries to implement land consolidation to provide land for various purposes without displacing local people from their area, housing, or agriculture. With the support of the law, Japan has intensively carried out land consolidation for a long time, known as Kukaku-Seiri or Land Readjustment for urban areas and Land Consolidation for rural areas. Japan's experience in implementing the Land Readjustment was transmitted to Indonesia in technical cooperation to assist the Indonesian government in achieving a good form of land consolidation.

Land Consolidation is a development model with elements related to land control policy issues to benefit roads and other basic infrastructure [9]. Land Consolidation includes a long process in which the stages include [10]:

1. Selection of the location of the object of land consolidation

2. Counseling to landowners;

3. The agreement of the prospective participants;

4. Identification of potential land consolidation objects;

5. Designation of land as the object of land consolidation;

6. Preparation of design for the implementation of land consolidation;

7. Release of physical rights over the land object for land consolidation;

8. Performance of physical activities;

9. Implementation of the allocation of replacement land units to participants 
10. Implementation of land allocation for infrastructure;

11. Sales of land units to replace land consolidation costs to interested parties;

12. Coaching and supervision.

\section{Methods}

The research approach method is normative research, conducted by examining library materials/secondary data and primary data. The specification of this research is descriptive analysis. It describes the study of the possibility of applying land consolidation as a method of land acquisition for developing and analyzing the possibility of land consolidation as a form of community participation in spatial planning. The research uses secondary data and is supported by primary data from interviews. The resource persons are government officials authorized to land consolidation research materials (The Agrarian Spatial Planning and Regional Planning Boards; The Directorate of Spatial Planning of the Ministry of Public Works; The Public Housing Service). This research is a follow-up study from the 2020 research conducted in the Tegalsari Village, Tegal City, Central Java.

\section{Result and discussion}

Land consolidation is considered necessary in housing development policies because land consolidation has characteristics; 1) the implementation procedure respects land rights and upholds justice by involving the active participation of landowners through deliberation in every decision making, both in the planning stage and in the planning stage; 2) the landowner is managed not to be evicted from the environment; 3 ) the profits obtained from the increase in the added value of the land and the implementation costs are distributed fairly to the community who owns the land participating in the consolidation; 4) the arrangement of land tenure is carried out simultaneously with the performance of land use and land certification which has been consolidated; 5) implementation costs are managed from the landowner so that they do not only rely on minimal government fees; 6) the use of land is managed efficiently and optimally by referring to the Regional Spatial Plan (RTRW), at the same time providing land for the necessary facilities and infrastructure to support local government policies.

Based on interviews and field discussions, several conditions that characterize land management problems can be seen in Table 1. Although land consolidation has quite interesting characteristics and has been regulated for 20 years, its implementation has not shown maximum results, even though it is only limited to land consolidation for land management in residential areas.

Table 1. Mapping land consolidation Planning.

\begin{tabular}{|c|c|c|}
\hline $\begin{array}{c}\text { Condition of Land } \\
\text { Consolidation } \\
\text { Program }\end{array}$ & Community & Government \\
\hline $\begin{array}{c}\text { Implementation } \\
\text { Procedure }\end{array}$ & $\begin{array}{c}\text { More socialization is needed } \\
\text { regarding the benefits of Land } \\
\text { Consolidation }\end{array}$ & $\begin{array}{c}\text { We don't have an } \\
\text { operational framework yet }\end{array}$ \\
\hline Residential Placement & $\begin{array}{c}\text { The choice of the community to } \\
\text { remain inhabited without being } \\
\text { moved }\end{array}$ & $\begin{array}{c}\text { Requires an assessment of } \\
\text { the length of stay, etc }\end{array}$ \\
\hline Land Value Increase & $\begin{array}{c}\text { Some people are not fully aware of } \\
\text { the benefits of Land Consolidation }\end{array}$ & $\begin{array}{c}\text { Advantages of supporting } \\
\text { Regional Spatial Planning } \\
\text { (RTRW) }\end{array}$ \\
\hline
\end{tabular}




\begin{tabular}{|c|c|c|}
\hline $\begin{array}{c}\text { Condition of Land } \\
\text { Consolidation } \\
\text { Program }\end{array}$ & Community & Government \\
\hline $\begin{array}{c}\text { Land Arrangement and } \\
\text { Certification }\end{array}$ & $\begin{array}{c}\text { Support the legal force of land } \\
\text { ownership }\end{array}$ & $\begin{array}{c}\text { Support land certification } \\
\text { programs and land data } \\
\text { collection }\end{array}$ \\
\hline Implementation cost & $\begin{array}{c}\text { The condition of the community } \\
\text { has not entirely been able to } \\
\text { finance land consolidation. }\end{array}$ & $\begin{array}{c}\text { Limited implementation } \\
\text { costs }\end{array}$ \\
\hline $\begin{array}{c}\text { Provision of } \\
\text { Infrastructure }\end{array}$ & $\begin{array}{c}\text { Strongly supports the development } \\
\text { of Public Space for the community }\end{array}$ & $\begin{array}{c}\text { Keeping Green Open Space } \\
\text { according to the Regional } \\
\text { Spatial Plan (RTRW) }\end{array}$ \\
\hline
\end{tabular}

Furthermore, the implementation of land consolidation also has problems caused by several things as follows (Table 2)

Table 2. Mapping land consolidation Program.

\begin{tabular}{|c|c|c|}
\hline $\begin{array}{c}\text { Planning } \\
\text { Constraints }\end{array}$ & Should & Possible Approaches \\
\hline \multirow{3}{*}{$\begin{array}{l}\text { Implementation } \\
\text { time and process }\end{array}$} & $\begin{array}{l}\text { Must build adequate environmental } \\
\text { facilities and infrastructure for a } \\
\text { housing environment or livable } \\
\text { residential area. }\end{array}$ & $\begin{array}{l}\text { Some have been carried out } \\
\text { through the KOTAKU program. }\end{array}$ \\
\hline & $\begin{array}{l}\text { According to their original use, the } \\
\text { government must prepare land for } \\
\text { infrastructure facilities, although } \\
\text { with a smaller area. }\end{array}$ & $\begin{array}{l}\text { Collaborating with the private } \\
\text { sector through CSR }\end{array}$ \\
\hline & It costs a lot & $\begin{array}{l}\text { Need sources of funds from the } \\
\text { private sector (CSR and grants) }\end{array}$ \\
\hline \multirow[b]{2}{*}{ Land Owner } & $\begin{array}{l}\text { Lack of comprehensive knowledge } \\
\text { of the benefits of being a } \\
\text { participant in land consolidation }\end{array}$ & $\begin{array}{c}\text { Need intensive socialization to } \\
\text { local institutions } \\
\text { BKM/RT/RW/PKK }\end{array}$ \\
\hline & $\begin{array}{l}\text { Community landowners do not } \\
\text { fully understand the value of the } \\
\text { benefits obtained economically, } \\
\text { socially, and ecologically from } \\
\text { their participation in land } \\
\text { consolidation. }\end{array}$ & $\begin{array}{c}\text { Socialization by ATR/BPN } \\
\text { agencies and Local Government }\end{array}$ \\
\hline
\end{tabular}

Against the obstacles in the implementation of land consolidation above, the government can seek a solution. The government needs to formulate development activities for the public interest in which land can be provided through the land consolidation method. However, land acquisition can be carried out using the consolidation method in development activities such as structuring settlements, roads, environmental drainage, sports and children's play facilities, education, and health facilities.

With the solution above, of course, the government's work becomes more complex, more expensive, and more time-consuming. However, the government can cooperate with the private sector in Public-Private Partnerships (PPP). This public-private partnership first appeared in the United States in project funding of educational programs.

In particular, consolidation participants will gain economic, sociological, and ecological benefits. This is important because we are often trapped in conventional development patterns that link economic benefits with social and environmental costs. The three elements 
of development (economic, social, and ecological) must consciously be considered in planning, policy, and development processes. Thus, if a person's land due to consolidation is no longer suitable for habitation and must move, then he or she can move to a location not too far from the original site before the merger. The owners of the consolidated land must continue to live around the original location in an economically, socially, and ecologically viable area.

Based on the advantages mentioned above, land consolidation should be seriously considered a land acquisition method for development in the public interest that upholds the principles of justice and community participation. The principle of justice is a principle that guarantees proper compensation to those who are entitled to the land acquisition process so that they get the opportunity to be able to carry out a better life. In this case, a proper replacement is identified with a comfortable and safe environment. The principle of participation is support in land acquisition through community participation, either directly or indirectly, from planning to development activities.

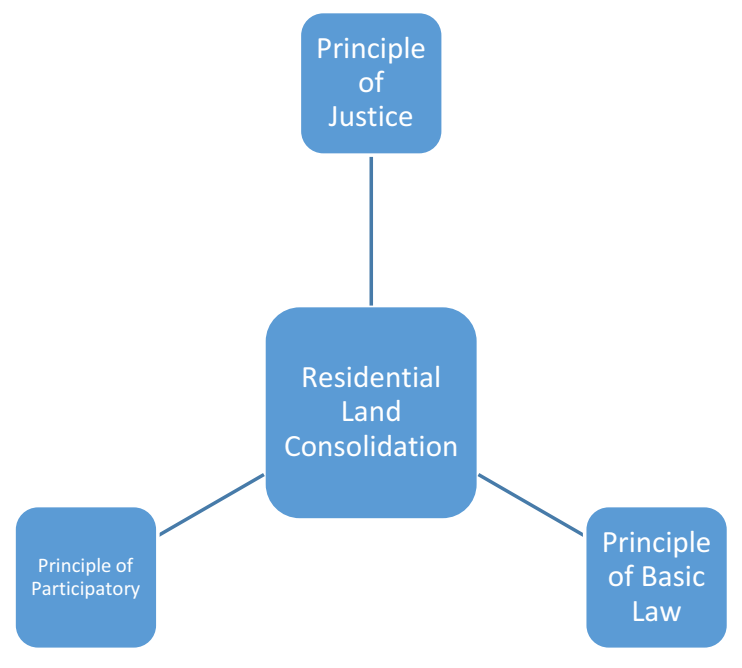

Fig. 1. Three basic methods of implementing land consolidation in Tegal.

Community participation has an essential role in the realization of land acquisition through the consolidation method. From spatial planning, community participation is manifested in the part of the community in the spatial planning process, which is outlined in the legal form of PP no. 68 of 2010 concerning Forms and Procedures for Community Roles in Spatial Planning. Moreover, from a legal perspective, land consolidation must be regulated at least in the form of government regulations so that land consolidation as a form of community participation has a solid legal basis (Figure 1).

So that it is necessary to formulate the reference provisions in the law on Land Procurement for Development. Land condition for housing and settlement areas through land consolidation has been confirmed in Article 113 of Law no. 1 of 2011.

Suppose the land acquisition activity is carried out through the land consolidation method. In that case, this priority right of the government becomes a guarantee for the owners of the consolidated land to get their land back in a more appropriate and certified social and ecological environmental condition. This is in line with one of the individual rights in spatial planning, namely enjoying the added value of space resulting from spatial planning (Article 60 of the Spatial Planning Law). If it is associated with the philosophy of land consolidation, 
the added value of space is to build without displacing it. It must be interpreted to add value economically and socially, culturally, and environmentally quality.

The land consolidation program is an essential instrument for integrating integrated and participatory spatial planning and regional development. It was incorporated in the sense of integrating various stakeholder interests. At the same time, participatory is implementing the provisions of Article 65 of the Spatial Planning Law, which requires the implementation of spatial planning to involve the role of the community either through community participation in the preparation of spatial plans and control of space utilization. In these three stages, the owners of the consolidated land can participate directly in land acquisition for development with the technical provisions referring to the Regulation of the Head of ATR/BPN No. 4 of 1991 concerning Land Consolidation. Meanwhile, for the construction sector, it refers to the relevant sector regulations. It is considering that land consolidation can be a method of land acquisition for development that prioritizes the principles of participation and justice. Land consolidation can also be used as an instrument to realize participatory spatial planning and realize integrated regional development with Tegal and its surroundings.

\section{Conclusion}

It requires commitment, hard work from all parties (stakeholders), and prioritizing the spirit of togetherness to create a safe, comfortable, productive, and sustainable city space and realize development that prioritizes social, cultural, and environmental friendliness. Whatever the orientation of economic growth is carried out, it must still achieve social justice. Moreover, products for the public interest must incur as little social and environmental costs as possible to make the slum community safe, comfortable, and socially justice.

In other words, consolidation aims to reorganize the form and ownership of land to be effective and efficient. Land consolidation is carried out for the public interest to improve environmental quality, provide public spaces, and maintain natural resources by involving the active participation of the community. The three principles of land consolidation (justice, active community participation, and legal regulations) have enormous potential to provide land needs, such as providing low-income housing, structuring slum areas, and infrastructure development. However, in reality, the implementation of land consolidation is not as easy as turning the palm to solve land problems for housing provision. Furthermore, local governments, academics, practitioners, the private sector, and the community have equally essential functions, requiring mature collaboration to implement land consolidation successfully.

The authors would like to thank the Indonesian Ministry of Research and Technology for funding this research. In addition, the authors would also like to thank the Department of Urban and Regional Planning, Engineering Faculty, Diponegoro University, and all who have helped this research.

\section{References}

[1] N. Yuliastuti Y. Widiastomo, Towards better social housing policy based on residents' satisfaction: A Case study at Sendangmulyo, Semarang, Indonesia, J. Sustain. Dev., 8(2), 149 (2015)

[2] A. Hariyanto, Strategi penanganan kawasan kumuh sebagai upaya menciptakan lingkungan perumahan dan permukiman yang sehat (Contoh kasus: Kota Pangkalpinang), J. Perenc. Wil. dan Kota UNISBA, 7(2), 11-37 (2007)

[3] R. Haryanto, I. Buchori, N. Yuliastuti, I. Saleh, A. Sugiri, B. Nuari, N. R. Putri, 
Preparedness to implement a spatial plan: The Impact of the land cooperative in Central Bangka Regency, Sustain., 12(24), 1-19 (2020)

[4] O. Sitorus, B. Sebayang, Konsolidasi tanah perkotaan: Suatu tinjauan hukum, Mitra Kebijakan Tanah Indonesia, (1996)

[5] B. D. Ramdani, R. Haryanto, Preferensi masyarakat terhadap penataan kawasan permukiman nelayan kumuh di Desa Kurau, Kecamatan Koba, Kabupaten Bangka Tengah, Tek. PWK (Perencanaan Wil. Kota), 2(3), 569-577(2013)

[6] N. Yuliastuti, R. Haryanto, The Implementation of land consolidation policy for housing development, in E3S Web of Conferences, 202, 6035 (2020)

[7] D. Demetriou, L. See, J. Stillwell, A Parcel shape index for use in land consolidation planning, Trans. GIS, 17(6), 861-882 (2013)

[8] A. K. Munnangi, B. Lohani, S. C. Misra, A Review of land consolidation in the state of uttar Pradesh, India: Qualitative approach, Land use policy, 90, 104309 (2020)

[9] A. Yuriwin, Bahan Ajar Konsolidasi Tanah, (Dirktbpnri Jakarta 2010)

[10] Hasni, Hukum penataan ruang dan penatagunaan tanah dalam konteks UUPAUUPRUUPPLH, (Rajagrafindo Persada Jakarta 2016) 